\title{
Treatment After Crizotinib Resistance in ALK+ Non-Small-Cell Lung Cancer
}

\author{
Seher N. KAZAZ ${ }^{1}$, Ilhan OZTOP² \\ ${ }^{1}$ Kanuni Research and Training Hospital, Medical Oncology, Trabzon \\ ${ }^{2}$ Dokuz Eylül University, Institute of Oncology, Department of Medical Oncology, Izmir, TURKEY
}

\begin{abstract}
Systemic chemotherapy, genotype-based targeted therapies and immunotherapy are widely used in the treatment of advanced nonsmall-cell lung cancer (NSCLC). Among the targeted therapies, the agents targeting the epidermal growth factor receptor (EGFR), the echinoderm microtubule-associated protein-like 4 anaplastic lymphoma kinase (EML4-ALK) rearrangement and C-ros oncogene 1 (ROS-1) have currently become standard treatment for cases presenting such molecular anomalies. Of them, cases with ALKrearrangement displayed dramatic results with a first generation ALK-inhibitor crizotinib; however, most of the patients develop a resistance in a few years. Especially the central nervous system relapses pose the most common clinical problem. Next generation ALK-inhibitors are promising with a high level of effectiveness in this resistance, in which various molecular mechanisms take part. Also, it gains increasing importance to re-perform a biopsy in the progression stage and reveal the mechanisms causing the secondary resistance in those patients.
\end{abstract}

Keywords: Non-small-cell lung cancer, ALK, Crizotinib, Resistance

\section{ÖZET}

\section{ALK-Pozitif Küçük Hücreli Dışı Akciğer Kanserinde Crizotinib Direnci Sonrası Tedavi}

İleri evre küçük hücreli dışı akciğer kanseri (KHDAK)'nin tedavisinde sistemik kemoterapi, genotipe dayalı hedef tedaviler ve immunoterapi yaygın olarak kullanımaktadır. Hedef tedaviler arasında epidermal growth factor receptor (EGFR), the echinoderm microtubule-associated protein-like 4 anaplastic lypmhoma kinase (EML4-ALK) rearrangement ve C-ros oncogene 1 (ROS-1)'i hedefleyen ajanlar, bugün için bu moleküler anormalliklere sahip hastalarda standard tedavi haline gelmiştir. Bunlardan ALK-rearrangement'i olan hastalarda birinci jenerasyon ALK-inhibitörü crizotinib ile dramatik sonuçlar elde edilmiş olmakla birlikte hastaların çoğunda birkaç yıl içinde direnç gelişmektedir. Özellikle santral sinir sistemi relapsları en sık karşılaşılan klinik sorun olarak karşımıza çıkmaktadır. Çeşitli moleküler mekanizmaların rol oynadığı bu direnç durumunda yeni jenerasyon ALK-inhibitörleri yüksek etkinlikleri ile ümit vadetmektedir. Ayrıca bu hastalarda progresyon aşamasında tekrar biyopsi yapılması ve sekonder dirence neden olan mekanizmaların ortaya konması giderek önem kazanmaktadır.

Anahtar Kelimeler: Küçük hücreli dışı akciğer kanseri, ALK, Crizotinib, Direnç 


\section{INTRODUCTION}

Lung cancer is the primary cause of cancer-related death worldwide, causing approximately 1.5 million deaths every year. ${ }^{1}$ Non-small-cell lung cancer (NSCLC) cases comprise approximately around $85 \%$ of all lung cancers. More than half of the NSCLC cases are advanced-stage at the time of diagnosis, and those patients' 5 -year survival rate is around $4 \% .^{2}$ In the advanced-stage disease, histology-based systemic chemotherapy and genotype-based targeted therapies comprise the main treatment approaches. Today, among the genotypebased targeted therapies, specific tyrosine kinase inhibitors (TKI), erlotinib, gefitinib and afatinib that target the Epidermal Growth Factor Receptor (EGFR); and crizotinib that targets the echinoderm microtubule-associated protein-like 4 anaplastic lymphoma kinase (EML4-ALK) rearrangement and C-ros oncogene 1 (ROS-1) are widely applied to patients with sensitive molecular anomalies.-5 Recently, positive results achieved in the field of immunotherapy have led to a growing number of treatment options.

ALK rearrangement is an oncogenic molecular anomaly observed in $2-7 \%$ of patients with NSCLC, and it is presented largely by young patients with a solid-pattern-dominant adenocarcinoma histology and without smoking history. ${ }^{6,7}$ Studies conducted with crizotinib, which inhibits the mesenchymal-epithelial transition factor (MET) and ROS1 alongside ALK, reported significant response rates and survival advantage both in the first line treatment and in patients who received prior treatment. Upon these developments, crizotinib became a primary treatment option widely applied to ALK+ positive patients. Although dramatic results have been achieved with crizotinib, median progression-free survival (PFS) do not exceed 1012 months, that is, patients present an acquired resistance after a while..$^{3-5}$ In this stage, especially the central nervous system (CNS) relapses pose the most common clinical problem. Numerous genetic mutations have been identified as resistance mechanisms to crizotinib, and specific inhibitors are being developed against them. The aim of this review is to evaluate the resistance mechanisms to crizotinib in ALK+ advanced-stage NSCLC and review the potential next generation agents studied to overcome this resistance.

\section{Clinical Results of Crizotinib:}

Crizotinib (PF-02341066) is a small oral molecule that was developed as a MET inhibitor at first. However, its ability to inhibit ALK and ROS- 1 was discovered later. A phase I (PROFILE 1001) ${ }^{8}$ and a phase II study (PROFILE 1005) ${ }^{9}$, conducted following the promising preclinical findings, calculated the overall response rate (ORR) to be around $60 \%$ and median PFS as 9 months. With those results, crizotinib received an accelerated approval from the Food and Drug Administration (FDA) in 2011.

Two phase III studies were conducted to examine the effectiveness of crizotinib on ALK + patients with NSCLC. In the PROFILE $1007^{10}$ study, 347 ALK+ NSCLC patients with a history of platinum-based chemotherapy were randomized into crizotinib vs. docetaxel or pemetrexed arms as the second line treatment. The findings showed that crizotinib was significantly superior to chemotherapy in terms of both ORR (65\% vs. $20 \%$, p $<0.001)$ and median PFS (7.7 months vs. 3.0 months, HR: 0.49). The PROFILE $1014^{11}$, another phase III study, compared crizotinib with platinum-based combined chemotherapy as the first line treatment. That study evaluated a total of 343 ALK+ patients with NSCLC, and the patients were randomized into crizotinib vs. platinum/pemetrexed combination arms as the first line treatment. The findings again showed that crizotinib was superior to chemotherapy in terms of both ORR $(74 \%$ vs. $45 \%, \mathrm{p}<0.001)$ and median PFS (10.9 months vs. 7.0 months, HR: 0.45). Crizotinib is generally well-tolerated, with reported main side effects including vision disorders, diarrhea, edema, high aminotransferase, and neutropenia (Table 1).

Although dramatic response rates and significantly prolonged progression-free survival rates are achieved with crizotinib, resistance is inevitable after a while. The phenomenon of progression, which emerges in 10-12 months following the start of treatment, is manifested as relapses involving multiple sites, particularly the central nervous system. Nevertheless, it may also manifest as oligoprogression in a small group of patients, which refers to progression in a limited number of sites. 
International Journal of Hematology and Oncology

\begin{tabular}{|c|c|c|c|c|c|}
\hline Agent & Researcher & Phase & Design & $\begin{array}{l}\text { ORR } \\
\text { (\%) }\end{array}$ & $\begin{array}{l}\text { Median PFS } \\
\text { (month) }\end{array}$ \\
\hline \multirow[t]{4}{*}{ Crizotinib } & Camidge et al8 (PROFILE 1001) & । & On different lines & 61 & 9.7 \\
\hline & Kim et al ${ }^{9}$ (PROFILE 1005) & $\|$ & Cases progressed after $\geq 1$ line of chemotherapy & 53 & 8.5 \\
\hline & Shaw et al' ${ }^{10}$ (PROFILE 1007) & III & $\begin{array}{l}\text { Crizotinib vs. Chemotherapy in the second line } \\
\text { treatment (Pemetrexed or Docetaxel) }\end{array}$ & 65 vs 20 & 7.7 vs 3.0 \\
\hline & Solomon et al'11 (PROFILE 1014) & III & $\begin{array}{l}\text { Crizotinib vs. Platinum+Pemetrexed in the } \\
\text { first line treatment }\end{array}$ & 74 vs 45 & 10.9 vs 7.0 \\
\hline
\end{tabular}

\section{RESISTANCE MECHANISMS to CRIZOTINIB}

Two primary mechanisms are reported to take part in the secondary resistance to crizotinib: secondary mutations in the EML4-ALK gene and the activation of alternative bypass signaling pathways.

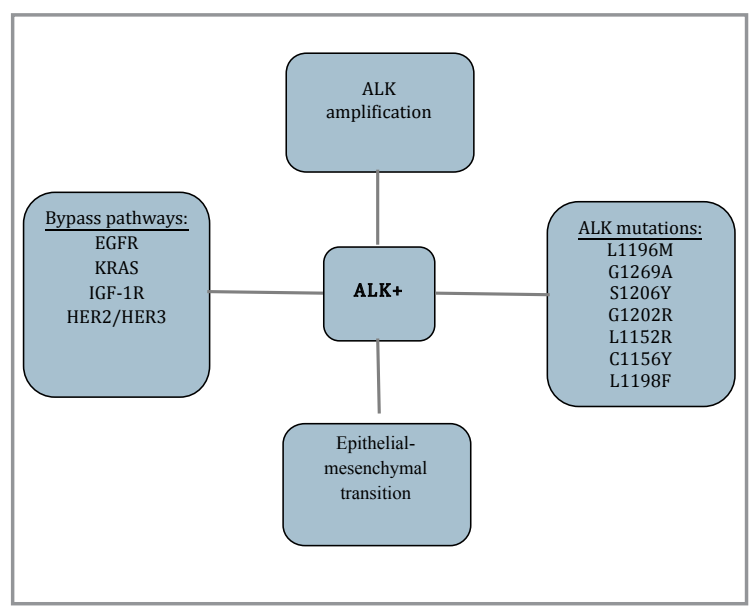

Figure 1. The molecular mechanisms of resistance to crizotinib

\section{Secondary Resistance Mutations in ALK:}

Secondary mutations in the ALK gene comprise approximately one-third of the causes of resistance. In this sense, the most frequently observed secondary mutation is L1196M; it arises with the addition of bulky residues to the adenosine triphosphate (ATP)-binding domain site, similar to the EGFR T790M gatekeeper mutation. Other mutations are identified as C1156Y, G1269A, F1174,
L1152R, S1206Y, G1202R, and D1203N. . $3,12-15^{3}$ The second generation ALK-inhibitors play a major role in those secondary mutations, which are the primary cause of resistance in cases progressed under crizotinib therapy (Table 2 and 3) (Figure 1).

\section{ALK Gene Copy Number Changes:}

An increased number of ALK fusion gene copies is a major reason for the secondary resistance and accounts for around $20 \%$ of the resistance mechanisms. This change may be observed alone or in combination with other secondary resistance mechanisms. ${ }^{16,17}$ However, it is reported that alterations in the number of gene copies play a relatively minor role in resistance due to the potent effects of next generation ALK-inhibitors ${ }^{3}$ (Figure 1).

\section{Bypass Pathways:}

The activation of alternative pathways occupies an important place among the resistance mechanisms to crizotinib. EGFR15 is the most common bypass escape mechanism among these bypass pathways stimulating proliferation independently of ALK, followed by insulin-like growth factor-1 receptor (IGF-1), cKIT, HER2/HER3, and SRC. ${ }^{3,15,18-21}$ Apart from them, the mTOR activation is also reported to induce resistance crizotinib by increasing autophagia in the ALK receptor (Figure 1).

\section{Epithelial-Mesenchymal Transition:}

In the epithelial-mesenchymal transition (EMT), tumor cells display a transition from epithelial properties to sarcomatoid properties, thus gaining a 
International Journal of Hematology and Oncology

\begin{tabular}{|c|c|c|c|c|c|}
\hline Agent & Researcher & Phase & Design & ORR (\%) & $\begin{array}{l}\text { Median PFS } \\
\text { (month) }\end{array}$ \\
\hline \multirow[t]{4}{*}{ Ceritinib } & Kim et a ${ }^{31}$ (ASCEND 1) & I & $\begin{array}{l}\text { Cases with a prior history of Chemotherapy, } \\
\text { with or without Crizotinib }\end{array}$ & 58 & 8.2 \\
\hline & Mok et a ${ }^{32}$ (ASCEND 2) & $\|$ & Patients with a history of Crizotinib & 54 & 5.7 \\
\hline & Felip et a ${ }^{33}$ (ASCEND 3) & $\|$ & Patients without a history of ALK-inhibitor & 63.7 & 11.1 \\
\hline & Scagliotti et al50 (ASCEND 5) & III & $\begin{array}{l}\text { Ceritinib vs. Chemotherapy in cases progressed } \\
\text { under Crizotinib }\end{array}$ & 39 vs 7 & 5.4 vs 1.6 \\
\hline \multirow[t]{3}{*}{ Alectinib } & Ou et al ${ }^{34}$ & $\|$ & Patients with a history of Crizotinib & 50 & 8.9 \\
\hline & Shaw et a ${ }^{35}$ & $\|$ & Patients with a history of Crizotinib & 48 & 8.1 \\
\hline & Nokihara et al ${ }^{37}$ (J-ALEX) & III & Alectinib vs. Crizotinib in the first line treatment & & $\begin{array}{l}\text { Not reached } \\
\text { vs } 10.2\end{array}$ \\
\hline Brigatinib & Camidge et $\mathrm{al}^{39}$ & $1 / 11$ & $\begin{array}{l}\text { Cases with advanced-stage cancer, including } \\
\text { those with ALK+NSCLC }\end{array}$ & 72 & 12.8 \\
\hline Lorlatinib & Shaw et a $\left.\right|^{43}$ & । & $\begin{array}{l}\text { ALK+ and ROS-1+ NSCLC cases with a history } \\
\text { of ALK-inhibitor }\end{array}$ & 40 & NR \\
\hline
\end{tabular}

potential for further spreading and causing an invasion. The EMT rate is not clear in the lung cancer but it is suggested that EMT markers are expressed at a higher rate in ALK+ patients. ${ }^{22}$ Kobayashi et al. ${ }^{23}$ reported a reduced expression of epithelial markers and increased sarcomatoid changes at the progression stage in a patient. Some suggest that this resistance mechanism may play a role in the developed resistance to both crizotinib and next generation ALK-inhibitors (Figure 1). ${ }^{3}$

Despite all those mechanisms, the resistance mechanism remains unknown in approximately $25 \%$ of the cases. Therefore, it is of great importance to reperform a biopsy to reveal resistance mechanisms at the progression stage.

\section{APPROACHES to OVERCOMING CRIZO- TINIB RESISTANCE}

\section{Influence of the Progression Type on the Clini- cal Decision:}

Before deciding on a new treatment option for a patient progressed during the ALK-TKI treatment, it is useful to identify the type of progression., ${ }^{3,24}$ In this sense, two types of progression have been described: oligoprogression and systemic progression. In oligoprogression, the primary tumor is under control, the disease progresses slowly and includes a limited number of intracranial or extracranial asymptomatic metastases. Usually, the lesions with a limited progression are subjected to a stereotactic ablative radiotherapy and TKI treatment is maintained, which is considered a proper approach in such cases..$^{25}$ In systemic progression, however, other treatment alternatives are recommended, systemic treatment in particular.

Since crizotinib has a limited transition to the CNS, the cases progressed under crizotinib therapy frequently display brain metastases. This is due to the pharmacokinetic properties of crizotinib; it has a low effectiveness in the CNS as it is a substrate for the p-glycoprotein, which is an efflux pump that prevents the accumulation of drugs in the CNS. ${ }^{26} \mathrm{In}$ a phase I study called PROFILE 1001, 10 patients with CSN metastasis underwent local radiotherapy and continued to receive crizotinib, those patients were reported to receive it without progression between 82 and 591 days. ${ }^{27} \mathrm{~A}$ combined analysis of PROFILE 1005 and 1007 studies evaluated 275 cases with asymptomatic brain metastasis. As part of the analysis, in which 166 of the cases were reported to have received chemotherapy before while 109 of them did not, the intracranial DCR was measured as $62 \%$ and $52 \%$ at week 12 and the time until intracranial disease progression was 13 months and 7 months, respectively. ${ }^{28}$

In cases developing a limited number of extracranial metastases under crizotinib therapy, clinicians sometimes prefer to apply local ablative therapy to those sites and continue crizotinib. This approach 
is based on a rationale that there are crizotinib-resistant clones in sites presenting limited progression; as part of a related study including 14 ALK+ NSCLC cases, clinicians continued to administer crizotinib following a local ablative therapy and secured an extra PFS advantage of 7 months. ${ }^{29}$ Therefore, in addition to a transition to the next generation ALK-inhibitors, to continue crizotinib following a local ablative therapy seems to be a proper option both in CNS-metastatic cases and the cases with oligometastatic extracranial metastasis.

\section{Next Generation ALK-inhibitors:}

Next generation ALK-inhibitors draw attention with their high effectiveness in cases progressed under crizotinib. Ceritinib, alectinib, brigatinib, and lorlatinib are among the primary next generation ALK-inhibitors developed in this context.

\section{Ceritinib:}

Ceritinib (LDK378) is an oral, ATP-competitive and selective ALK-inhibitor, it is 20 times more potent than crizotinib. ${ }^{30}$ As part of ASCEND-1, a phase I study, 146 ALK+ cases were administered crizotinib at a dose of $750 \mathrm{mg} /$ day. 163 of them had a history of crizotinib and the remaining 83 were crizotinib-naïve; the study found ORR as $53 \%$ and $66 \%$, respectively. Median PFS was found 8.2 months in the whole group, which remained at 6.9 months for the group of cases with a crizotinib history. ${ }^{31}$ Both FDA and EMA approvals were obtained with these results. As part of the ASCEND-2, a phase II study conducted subsequently, 140 patients with a history of crizotinib or chemotherapy were administered crizotinib at a dose of $750 \mathrm{mg}$ /day. Consequently, the ORR was $38.6 \%$, disease control rate (DCR) was $77.1 \%$, and median PFS was 5.7 months. ${ }^{32}$ However, the ASCEND-3 study including 124 patients who did not receive ALK-inhibitor before found the ORR as $63 \%$, DCR as $89.5 \%$, and median PFS as 11.1 months (Table 2). ${ }^{33}$

Ceritinib is highly effective in CNS metastases as well. Among the cases without a history of ALKinhibitor as part of ASCEND-2 and ASCEND-3 studies, no significant difference was detected be- tween the cases with intracranial disease and those with extracranial metastasis in terms ORR and PFS. ${ }^{32,33}$

\begin{abstract}
Alectinib:
Alectinib (CH5424802) is a potent second generation ALK-inhibitor. In addition to being effective in numerous mutations that play a role in crizotinib resistance, it is also an ROS-1 inhibitor. Two phase II studies examined the effectiveness of alectinib in the second line treatment. As part of the first one, 138 crizotinib-resistant cases were administered alectinib at a dose of $1200 \mathrm{mg} /$ day, and the ORR was $50 \%$, DCR was $69 \%$, and median PFS was 8.9 months. ${ }^{34}$ Likewise, in the second phase II study, 87 crizotinib-resistant cases were administered alectinib at a dose of $1200 \mathrm{mg} /$ day; the ORR was $48 \%$ and median PFS was 8.1 months. ${ }^{35}$ It obtained FDA approval with this finding.
\end{abstract}

Alectinib's effectiveness in the first line treatment has been investigated as well. As part of AF-001JP, a phase II study, ALK+ cases received alectinib as the first line treatment with $93.4 \%$ response rate and a median PFS of 29 months. ${ }^{36}$ A subsequent phase III study (J-ALEX) including Japanese patients randomized ALK+ cases into crizotinib vs. alectinib arms as the first line treatment. Consequently, alectinib was found superior to crizotinib in terms of median PFS (not reached vs. 10.2 months). This superiority was reported to be applicable to all subgroups (Table 2 ). ${ }^{37} \mathrm{We}$ are currently waiting for the findings of Global ALEX study, which features a similar design.

Alectinib also has a high level of effectiveness in the CNS metastases. The phase II studies conducted on crizotinib-resistant cases report CNS disease control rates between $83 \%$ and $89 \% .^{36}$ The CNS metastasis is the primary one; a complete response was achieved in $43 \%$ of the patients who had not received radiotherapy. Similarly, it was shown by J-ALEX study to display a higher effectiveness than crizotinib in cases with brain metastasis (HR: 0.08) ${ }^{37}$ Alectinib's not being a substrate of the glicoprotein efflux pump is considered the most important reason for its high effectiveness in the CNS metastases. $^{38}$ 


\section{Brigatinib:}

Brigatinib (AP26113) is a small molecule TKI, it inhibits ALK - including resistant ALK mutations -, ROS-1, and EGFR, including T790M. A phase I/II study conducted on ALK+ NSCLC patients found ORR as $69 \%$ and $100 \%$ in patients with and without a history of crizotinib, respectively. Likewise, median PFS was 56 weeks for the whole group, while it decreased to 47 weeks among those who had received crizotinib. ${ }^{39}$ Brigatinib has a high rate of crossing blood-brain barrier as well. In a retrospective analysis of 15 CNS-metastatic patients treated with brigatinib, intracranial response rate and disease control rate was found $53 \%$ and $86 \%$, respectively (Table 2 ). ${ }^{40}$

\section{Lorlatinib:}

Lorlatinib (PF-063922) is a small molecule TKI that is able to inhibit both ALK and ROS-1 with a high capacity of brain penetration. ${ }^{41,42}$ Especially its high effectiveness on the G1202R mutation in comparison to other agents is one of its major advantages. Alongside the fact that a phase I study demonstrated its high effectiveness in patients who had received ALK-inhibitor ${ }^{43}$, it is suggested that the observations indicating the re-occurrence of crizotinib sensitivity in patients progressed after lorlatinib bring a new dimension to the struggle against resistance (Table 2). ${ }^{44}$

\section{Other ALK-inhibitors:}

There are ongoing early phase studies on other next generation ALK-inhibitors such as ASP302645, X-396 $6^{46}$, TSR-011 ${ }^{47}$, entrectinib ${ }^{48}$ and CEP$28122^{49}$, as well as basket studies including a variety of malignancies.

\section{Other Approaches:}

\section{- Chemotherapy:}

One of the most important problems concerning treatment preferences for the patients progressed under crizotinib is to decide whether to choose widely-administered chemotherapy or next generation ALK-inhibitors. As part of the ASCEND-5 study conducted on this matter, 231 ALK+ NSCLC patients progressed under crizotinib were randomized into Ceritinib or Chemotherapy (Pemetrexed or Docetaxel) arms. According to the findings, Ceritinib was found superior in terms of ORR (39\% vs 7\%) and median PFS (5.4 months vs 1.6 months). No difference was detected in the overall survival due to the crossover after progression. ${ }^{50}$

\section{- Immunotherapy:}

Immunotherapy is another treatment alternative after a patient develops resistance to crizotinib. Regarding immunotherapy, which has recently drawn a great deal of attention, a series of studies have been conducted with various immune checkpoint inhibitors in the advanced-stage disease and remarkable findings have been achieved. In this sense, especially nivolumab, pembrolizumab and atezolizumab, which are inhibitors developed against the programmed death receptor-1 (PD1) and its ligand, i.e. programmed death ligand-1 (PD-L1), obtained FDA approval and found their way into treatment guidelines thanks to their high effectiveness. ${ }^{51-53}$

\section{The Approach After Progression under Crizotinib:}

Today, the most rational approach for the patients progressed under crizotinib seems to shift to the next generation ALK-inhibitors. However, since the transition to the CNS is limited, an alternative approach for patients presenting only a CNS progression may be to administer a local therapy such as radiotherapy and maintain Crizotinib. Chemotherapy does not seem to be a first preference due to its low effectiveness compared to the next generation ALK-inhibitors. Today, the subsequent administration of ALK-inhibitors is suggested to offer the best survival outcome, with median PFS and median OS reaching 17.4 and 49.4 months, respectively. ${ }^{54}$ On the other hand, it is still an important and pending question as to which one to be used among the next generation ALK-inhibitors. As there is no study comparing the next generation ALK-inhibitors with each other, and since each one acts on different mutations, one should ideally perform a re-biopsy during the progression stage and reveal the resistance pattern in order to pick up 


\begin{tabular}{|c|c|c|c|c|c|c|c|c|c|c|c|}
\hline & L1196M & G1269A/S & C1156Y & R1275Q & L1198F & S1206Y & I1171T & V1180L & F1174V/L & D1203N & G1202R \\
\hline Crizotinib $^{8-10}$ & -- & -- & -- & -- & + & -- & + & + & -- & -- & -- \\
\hline Ceritinib $^{31-33}$ & + & + & -- & + & -- & + & + & + & -- & -- & -- \\
\hline Alectinib $^{34,35}$ & + & + & + & + & -- & + & -- & -- & + & + & -- \\
\hline Brigatinib $^{39}$ & + & + & & & -- & & + & + & + & & + \\
\hline Lorlatinib $^{43}$ & + & + & + & & -- & + & & & + & & + \\
\hline
\end{tabular}

a relevant agent ${ }^{5}$ (Table 3). Nevertheless, re-biopsy sometimes becomes impossible due to the location of the primary tumor or patient's refusal. In such a case, molecular analyses may be performed based on the circulating tumor cell DNA (ctDNA) through a liquid biopsy. ${ }^{50}$ As the patients may potentially develop a resistance to the next generation ALK-inhibitors after a while, it is required to carry out repetitive tissue/liquid biopsies when progression takes place after each treatment.

In conclusion, crizotinib, a first generation ALKinhibitor, has long been the standard and routine approach for the advanced-stage NSCLC patients with ALK-rearrangement. Nevertheless, as the secondary resistance and hence progression becomes inevitable after a while, the principles of approach should be better established. Today, next generation ALK-inhibitors appear to be the best approach thanks to their high specific effectiveness and low toxicity profiles. Besides, shifting to immunotherapy and approaches for other pathways are other alternative options. Further clarification of the molecular patterns of the secondary resistance patterns will enable more specific treatments in the future.

\section{REFERENCES}

1. Siegel RL, Miller KD, Jemal A. Cancer statistics, 2015. CA Cancer J Clin 65: 5-29, 2015.

2. Rossi A. Alectinib for ALK-positive non-small-cell lung cancer, Expert Rev Clin Pharmacol 9: 1005-1013, 2016.

3. Dagogo-Jack I, Shaw T. Crizotinib resistance: implications for therapeutic strategies. Ann Oncol 27: ii42-ii50, 2016.

4. Qian M, Zhu B, Wang X, Liebman M. Drug resistance in ALKpositive non-small cell lung cancer patients. Semin Cell Dev Biol 16: 30314-30317, 2016.
5. Matikas A, Kentepozidis N, Georgoulias V, Kotsakis A. Management of resistance to crizotinib in anaplastic lymphoma kinase-positive non-small-cell lung cancer. Clin Lung Cancer 17: 474-482, 2016.

6. Vavala T, Monica V, Lo lacono M, et al. Precision medicine in age-specific non-small-cell-lung-cancer patients: integratingbiomolecular results into clinical practice-A new approach to improvepersonalized translational research. Lung Cancer pii: S0169-5002 30348-8, 2016

7. Rangachari D, Yamaguchi N, VanderLaan PA, et al. Brain metastases in patients with EGFR-mutated orALK-rearranged non-small-cell lung cancers. Lung Cancer 88: 108-111, 2015.

8. Camidge DR, Bang YJ, Kwak EL, et al. Activity and safety of crizotinib in patients with ALK-positive non-small-cell lung cancer: updated results from a phase 1 study. Lancet Oncol 13: 1011-1019, 2012.

9. Kim D, Ahn M, Shi Y, et al. Updated results of a global phase II study with crizotinib in advanced ALK-positive non-small cell lung cancer (NSCLC). J Clin Oncol 2012; 30(suppl), abstract 7533.

10. Shaw AT, Kim DW, Nakagawa K, et al. Crizotinib versus chemotherapy in advanced ALK-positive lung cancer. N Engl J Med 368: 2385-2394, 2013.

11. Solomon BJ, Mok T, Kim DW, et al. First-line crizotinib versus chemotherapy in ALK-positive lung cancer. N Engl J Med 371: 2167-2177, 2014.

12. Choi YL, Soda M, Yamashita $Y$, et al. EML4-ALK mutations in lung cancer that confer resistance to ALK inhibitors. N Engl $J$ Med 363: 1734-1739, 2010.

13. Doebele RC, Pilling AB, Aisner DL, et al. Mechanisms of resistance to crizotinib in patients with ALK gene rearranged nonsmall cell lung cancer. Clin Cancer Res 18: 1472-1482, 2012.

14. Toyokawa G, Hirai F, Inamasu E, et al. Secondary mutations at 11171 in the ALK gene confer resistance to both Crizotinib and Alectinib. J Thorac Oncol 9: e86-e87, 2014.

15. Katayama R, Shaw AT, Khan TM, et al. Mechanisms of acquired crizotinib resistance in ALK-rearranged lung cancers. Sci Transl Med 4: 120ra17, 2012.

16. Doebele RC, Pilling AB, Aisner DL, et al. Mechanisms of resistance to crizotinib in patients with ALK gene rearranged nonsmall cell lung cancer. Clin Cancer Res 18: 1472-1482, 2012. 
17. Katayama R, Khan TM, Benes C, et al. Therapeutic strategies to overcome crizotinib resistance in non-small cell lung cancers harboring the fusion oncogene EML4-ALK. Proc Natl Acad Sci USA 108: 7535-7540, 2011.

18. Tanizaki J, Okamoto I, Okabe T, et al. Activation of HER family signaling as a mechanism of acquired resistance to ALK inhibitors in EML4-ALK-positive nonsmall cell lung cancer. Clin Cancer Res 18: 6219-6226, 2012.

19. Lovly CM, McDonald NT, Chen $\mathrm{H}$, et al. Rationale for co-targeting IGF-1R and ALK in ALK fusion-positive lung cancer. Nat Med 20: 1027-1034, 2014.

20. Wilson $\mathrm{FH}$, Johannessen $\mathrm{CM}$, Piccioni $\mathrm{F}$, et al. A functional landscape of resistance to ALK inhibition in lung cancer. Cancer Cell 27: 397-408, 2015.

21. Crystal AS, Shaw AT, Sequist LV, et al. Patient-derived models of acquired resistance can identify effective drug combinations for cancer. Science 346: 1480-1486, 2014.

22. Kim H, Jang SJ, Chung DH, et al. A comprehensive comparative analysis of the histomorphological features of ALKrearranged lung adenocarcinoma based on driver oncogene mutations: frequent expression of epithelial-mesenchymal transition markers than other genotype. PLoS One 8: e76999, 2013.

23. Kobayashi $Y$, Sakao $Y$, Ito S, et al. Transformation to sarcomatoid carcinoma in ALK-rearranged adenocarcinoma, which developed acquired resistance to crizotinib and received subsequent chemotherapies. J Thorac Oncol 8: e75-e78, 2013.

24. Romanidou O, Landi L, Cappuzzo F, Califano R. Overcoming resistance to first/second generation epidermal growth factor receptor tyrosine kinase inhibitors and ALK inhibitors in oncogene-addicted advanced non-small cell lung cancer. Ther Adv Med Oncol 8: 176-187, 2016.

25. Weickhardt AJ, Scheier B, Burke JM, et al. Local ablative therapy of oligoprogressive disease prolongs disease control by tyrosine kinase inhibitors in oncogeneaddicted non-smallcell-lung cancer. J Thorac Oncol 7: 1807-1814, 2012.

26. Costa DB, Kobayashi S, Pandya SS, et al. CSF concentration of the anaplastic lymphoma kinase inhibitor crizotinib. J Clin Oncol 29: 443-445, 2011.

27. Camidge DR, Bang YJ, Kwak EL, et al. Activity and safety of crizotinib in patients with ALK-positive non-small-cell lung cancer: updated results from a phase 1 study. Lancet Oncol 13: 1011-1019, 2012.

28. Costa DB, Shaw AT, Ou SH, et al. Clinical experience with crizotinib in patients with advanced ALK-rearranged non-smallcell lung cancer and brain metastases. J Clin Oncol 33: 18811888, 2015.

29. Weickhardt AJ, Scheier B, Burke JM et al. Local ablative therapy of oligoprogressive disease prolongs disease control by tyrosine kinase inhibitors in oncogene-addicted non-small-cell lung cancer. J Thorac Oncol 7: 1807-1814, 2012.
30. Friboulet L, Li N, Katayama R, et al. The ALK inhibitor ceritinib overcomes crizotinib resistance in non-small cell lung cancer. Cancer Discov 4: 662-673, 2014.

31. Kim D, Mehra R, Tan D, et al. Ceritinib in advanced anaplastic lymphoma kinase (ALK)-rearranged (ALK+) non-small cell lung cancer (NSCLC): results of the ASCEND-1 trial. ASCO Annual Meeting, Chicago, May 30-June 03, 2014. J Clin Oncol 2014; 32(suppl):5s, abstract p8003.

32. Mok T, Dpigel D, Felip E, et al. ASCEND-2: a single-arm, openlabel, multicenter phase II study of ceritinib in adult patients (pts) with ALK-rearranged (ALKs) non-small cell lung cancer (NSCLC) previously treated with chemotherapy and crizotinib (CRZ). ASCO Annual Meeting, Chicago, May 29-June 02, 2015. J Clin Oncol 2015; 33(suppl), abstract p8059.

33. Felip E, Orlov S, Park K, et al. ASCEND-3: a single-arm, openlabel, multicenter phase II study of ceritinib in ALKi-naïve adult patients (pts) with ALK-rearranged (ALKs) non-small cell lung cancer (NSCLC). ASCO Annual Meeting, Chicago, May 29June 02, 2015. J Clin Oncol 2015; 33(suppl), abstract p8060.

34. Ou SI, Ahn JS, De Petris L, et al. Alectinib in crizotinib-refractory ALK-rearranged non-small-cell lung cancer: a phase ॥ global study. J Clin Oncol 34: 661-668, 2016.

35. Shaw AT, Gandhi L, Gadgeel S, et al. Alectinib in ALK-positive, crizotinibresistant, non-small-cell lung cancer: a single-group, multicentre, phase 2 trial. Lancet Oncol 17: 234-242, 2016.

36. Ohe Y, Nishio M, Kiura K, et al. A phase I/II study with a CNSpenetrant, selective ALK inhibitor alectinib in ALK-rearranged non-small cell lung cancer (ALK+ NSCLC) patients (pts): updates on progression free survival (PFS) and safety results from AF-001JP. J Clin Oncol 2015; 33(suppl), abstract 8061.

37. Nokihara H, Hida T, Kondo M, et al. Alectinib (ALC) versus crizotinib (CRZ) in ALK-inhibitor naive ALK-positive non-small cell lung cancer (ALK+ NSCLC): Primary results from the J-ALEX study. ASCO 2016. Abstract 9008.

38. Kodama T, Hasegawa M, Takanashi K, et al. Antitumor activity of the selective ALK inhibitor alectinib in models of intracranial metastases. Cancer Chemother Pharmacol 74: 1023-1028, 2014.

39. Camidge R, Bazhenova L, Salgia R, et al. Safety and efficacy of brigatinib (AP26113) in advanced malignancies, including ALKs nonesmall cell lung cancer (NSCLC). J Clin Oncol 2015; 33(suppl), abstract 8062.

40. Gettinger SN, Bazhenova L, Salgia R, et al. Brigatinib (AP26113) Efficacy and safety in ALK+ NSCLC: phase 1/2 trial results. 16th World Conference on Lung Cancer, Denver, September 6-9, 2015. J Thorac Oncol 2015; 10(Suppl. 2): S66s890.

41. Zou HY, Friboulet L, Kodack DP, et al. PF-06463922, an ALK ROS1 inhibitor, overcomes resistance to first and second generation ALK inhibitors in preclinical models. Cancer Cell 28: 70-81, 2015. 
42. Zou HY, Li Q, Engstrom LD, et al. PF-06463922 is a potent and selective nextgeneration ROS1/ALK inhibitor capable of blocking crizotinib-resistant ROS1 mutations. Proc Natl Acad Sci USA 112: 3493-3498, 2015.

43. Shaw A, Bauer T, Felip E, et al. Clinical activity and safety of PF-06463922 from a dose escalation study in patients with advanced ALK+ or ROS1+ NSCLC. ASCO Annual Meeting, Chicago, May 29-June 02, 2015. J Clin Oncol 2015; 33(suppl), abstract p8018.

44. Shaw AT, Friboulet L, Leshchiner I, et al. Resensitization to crizotinib by the lorlatinib ALK resistance mutation L1198F. N Engl J Med 74: 54-61, 2016.

45. Patnaik A, LoRussa $P$, Ball $H$, et al. Pharmacokinetics and safety of an oral ALK inhibitor, ASP3026, observed in a phase I dose escalation trial. J Clin Oncol 2013; 31(suppl), abstract 2602.

46. Horn L, Infante J, Blumenschein $G$, et al. A phase I trial of X-396, a novel ALK inhibitor, in patients with advanced solid tumors. J Clin Oncol 2014; 32(suppl):5s, abstract 8030.

47. Weiss G, Sachdev J, Infante J, et al. Phase (Ph) 1/2 study of TSR-011, a potent inhibitor of ALK and TRK, including crizotinib-resistant ALK mutations. J Clin Oncol 2014; 32(suppl), abstract e19005.

48. De Braud F, Niger M, Damian S, et al. Alka-372-001: first-inhuman, phase I study of entrectinib_-an oral pan-TRK, ROS1, and ALK inhibitor-in patients with advanced solid tumors with relevant molecular alterations. J Clin Oncol 2015; 33 (suppl), abstract 2517.

49. Cheng M, Quail MR, Gingrich DE, et al. CEP-28122, a highly potent and selective orally active inhibitor of anaplastic lymphoma kinase with antitumor activity in experimental models of human cancers. Mol Cancer Ther 11: 670-679, 2012.

50. Scagliotti G, Kim TM, Crino L, et al. Ceritinib vs chemotherapy (CT) in patients (pts) with advanced anaplastic lymphoma kinase (ALK)-rearranged (ALK+) non-small cell lung cancer (NSCLC) previously treated with CT and crizotinib (CRZ): results from the confirmatory phase 3 ASCEND- 5 study. ESMO Copenhagen, October 7-11, 2016. Abstract LBA42, 2016.
51. Brahmer J, Reckamp KL, Baas P, et al. Nivolumab versus docetaxel in advanced squamous-cell non-small-cell lung cancer. N Engl J Med 373: 123-135, 2015.

52. Herbst RS, Baas P, Kim DW, et al. Pembrolizumab versus docetaxel for previously treated, PD-L1-positive, advanced non-small-cell lung cancer (KEYNOTE-010): a randomized controlled trial. Lancet 9: 1540-1550, 2016.

53. Fehrenbacher L, Spira A, Ballinger M, et al. Atezolizumab versus docetaxel for patients with previously treated non-smallcell lung cancer (POPLAR): a multicentre, open-label, phase 2 randomised controlled trial. Lancet 30: 1837-1846, 2016.

54. Gainor JF, Tan DS, De Pas T et al. Progression-free and overall survival in ALKpositive NSCLC patients treated with sequential crizotinib and ceritinib. Clin Cancer Res 21: 2745-2752, 2015.

\section{Correspondence:}

Dr. Ilhan ÖZTOP

Dokuz Eylül Üniversitesi

Onkoloji Enstitüsü

Tibbi Onkoloji Bilim Dali

Inciralti

IZMIR / TURKEY

Tel: (+90-232) 4125801

e-mail: ilhan.oztop@deu.edu.tr 